\title{
Visual Assessment of Methods of Street Furniture Installation Using Kansei Engineering (Case Study: Benches in the Historical-Cultural Area of Tabriz)
}

\author{
Mohammadali Haddadian ${ }^{1}$ \\ ${ }^{1}$ Lecturer in Industrial Design, faculty of Islamic Design, Tabriz Islamic Art University, Iran \\ Correspondence: Lecturer in Industrial Design, faculty of Islamic Design, Tabriz Islamic Art University, Iran. \\ E-mail: a.haddadian@tabriziau.ac.ir
}

Received: March 12, 2016

Accepted: March 25, 2016

Online Published: April 10, 2016

doi:10.5539/mas.v10n6p171

URL: http://dx.doi.org/10.5539/mas.v10n6p171

\begin{abstract}
Inappropriate development and rapid growth of metropolitan areas, with no facilities and infrastructure had serious negative consequences on different parts of the city that public programs organization and urban environments, including urban furniture, is considered one Sustainable urban development constructive approach that aimed at improving the quality of urban environment and various human needs. One of the humanitarian needs in urban areas creating a beautiful environment, orderly, attractive and diverse for citizens (Zangiabadi and Tabrizi, 5:2009).

Our cities and metropolis filled with a variety of elements and furniture that are ugly and some beautiful that as form and diversity, have little differences in different cities. Nevertheless it can be seen that the appearance and furniture with good design, installed so ugly and carelessly, its placement has changed adornment and lose their visual effects that has adverse effects on the furniture and the beauty of the surrounding environment and which is the importance and necessity of this research.
\end{abstract}

Keywords: urban furniture, visual assessment, installation, kansei engineering

\section{Introduction}

Urban furniture, more than any other associated with group of people and one of the pillars forming the image of the city, such as designing, manufacturing, installation, placement and maintenance they require deep and accurate study finds .

As one of the major city of Tabriz in Iran and with regard to the age and history of the town and numerous domestic and foreign tourists and hits it, the necessity of the existing furniture in it is clear from the above comments. Case studies in this research, historical-cultural city of Tabriz benches in the area located in region 8 of the city, which has attracted a lot of attention to domestic and foreign tourists.

Bench is one of the most widely used urban furniture in our country. Here location and position in space of urban furniture is considered, but issues related to the installation of urban furniture on other issues such as design, production and effective placement is subject. The default is an urban furniture must be design and product and installed.

When designing urban furniture designer must take into account the criteria of installation and placemen. Previous furniture without thinking about installing a good idea at the application site cannot bring the desired result. It is expected that at the end of the study could be a series of guidelines and recommendations for the installation of better urban furniture to enhance the beauty and visual quality they had in the city.

\section{Theory and Review in Literature}

\subsection{Urban, Urban Beauty and Urban Furniture}

City and urban life, the most striking achievements of human thought and effort. The idea behind its beauty and its ugliness result of concerted efforts defects and incorrect behavior of humans. Urban and urban culture is the right combination of elements can be an easy, well-being and safety to social aspects of human life is donated (Madanipour, 216,2001) 
Clint part of the construction of urban space that has been coordinated and continuous (Mumford, 1961) in terms of confining physical body (tavasoli, 1997) is. This space should be orderly and organized the city's beauty and activities (Zucker, 1956).

A basic condition for the space, urban public space is considered to interact and be social support, organized urban space element, decent and orderly, which acts as a platform for the activity of human behavior (Pakzad, 81: 2006)

With the rapid growth of urbanization of the 40s has forgotten urban identity and urban managers in quantities less Stowe urban issues such as organization and symmetry and order of the elements considered essential as the beauty of the city.

Beauty and urban spaces provided definitions of beauty are under the influence of culture and the dominant cultural model in every city, accordingly its interpretations and definitions of beauty will be changeable. (Behzadfar, 2013). But the factors that are known everywhere as symbols of urban beauty are as light color, form, and material. One of the main beautification activities in urban management, is urban furniture.

Urban furniture are said to a wide range of instruments, objects, devices, symbols, in buildings, spaces and elements and because they have been installed in the city, the streets and in the open space and have public use, are so called Urban furniture (Murtezai, 20:2003).

Based on the principles of urbanism, urban furniture should consider the social and cultural practices in the design and installation. Street furniture and equipment by identifying one place they help to create or improve urban spaces (Saeed nia, 16:1999).

Urban furniture is the best means to create fascination in urban environments. City will be maintained by them. Urban furniture is respecting the civil rights. Elements and urban furniture and beauty and adornment of them will be seen and judged by citizens.

Individual citizens is one who participate in social, political, cultural, economic, and community and his direct or indirect decision is effective (Pourtahmasi, 2002: 5). Citizens' Rights concerning the rights of the human innate and inalienable, non-violation (Dstmalchyan, 4:2002). One of the needs of the innate human is need for beauty and discipline.

Taking into account the characteristics and demands of the citizens in the design and urban furniture elements that have general application means sharing knowledge and life of citizens in municipal activities and the dynamics of the city. One of the first demands of the citizens is a beautiful city and the request for interactive spaces and tourist areas of the city becomes more important.

Tourism area, area in which the relationships and behaviors of individuals freely and arbitrarily shaped like talking, walking, experience and a sense of common area In addition, the possibility of debate and assembly and speech, etc., which ultimately leads to the creation of human solidarity and common interests.

A beautiful city has a positive impact on behavior and social norms citizens and urban furniture has direct impact on the beauty and adornment of beautiful city and a source of understanding urban furniture, beauty and adornment in their installation. How can reach beautiful urban furniture installation and maintained it?

\subsection{Kansei}

Kansei Engineering is one of the ways to translate perceptions, emotions and inner desires of customers to product design specifications to the perception of the product. (Klein and Khorram154:2009) as shooter describes: Kansei Engineering does not seek to develop a theory or a new tool. Kansei is a comprehensive methodology that includes rules for the interaction of different tools together to determine the effect on perception characteristics of a specific product users (Levy, 87: 2013)

If consider the product design process including three stages: information, idea generation and evaluation, most of the studies in the area of Kansei Engineering is focused in two phases: idea generation and evaluation, however, that the design process, between two forward Kansei Engineering will be backward (Nagamachy, 20: 2002)

Forward

Backward

Initial models

Initial foundation

Information 
Decision-Making-Valuation, Idea Creation

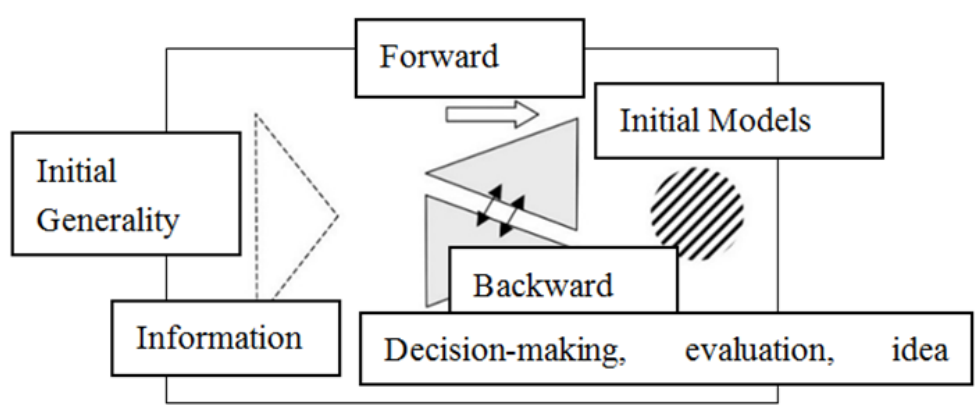

Figure 1. Visualization Kansei engineering cycle (Bouchard, 6: 2003)

Kansei engineering process forward, the contents of the data collected in the information phase, the original phrases and words that have been obtained from the evaluation of previous users or professionals in the market and the designers are design elements from various sources. Kanseiengineering process backward, the results forms the data (Bouchard, 6: 2003). In this study of Kansei engineering process forward is to use and the design data, obtained by the evaluation of words and terms that previous users forms it.

Words consider such as efficient tools to understand the feelings of the users are using Kansei Engineering. Kansei engineering, emotions going to be explained by physiological functions such actions and behaviors, body and face, words and physiological responses (e.g, heart rate) are discussed. Words reflect elements are actually using Kansei words, what the mind is. (Khodadadeh, 5.2009: 65-59).

\subsection{The Installation of Street Furniture}

Design and installation of street furniture in the area of responsibility of departments and organizations such as: telecommunications, electricity, water, traffic and bus the resulting un coordinated arrangement in the street. Select items and goods often due to their low cost andno attention to the suitability, durability and aesthetic advantages is paid it show more interest-oriented approach than weighed design (Saeed nia, S, 17:1999).

Three types of urban furniture installation is considered in general:

(A)Surface installation: The furniture directly on the surface like concrete surface with bolts or rivets special screws installed or placed on the surface, without any fixing.

(B) Installation of concrete blocks: Surface mount, but in this method as the basis for concrete (concrete foundation) has been proven (through bolt) and the same is installed. The surface like paving or asphalt can be placed on the concrete surface and cause clean surface around the base.

A: Root Installation: The base of the furniture is placed directly in the concrete mixture till itprepared to hold the hardened concrete foundation.

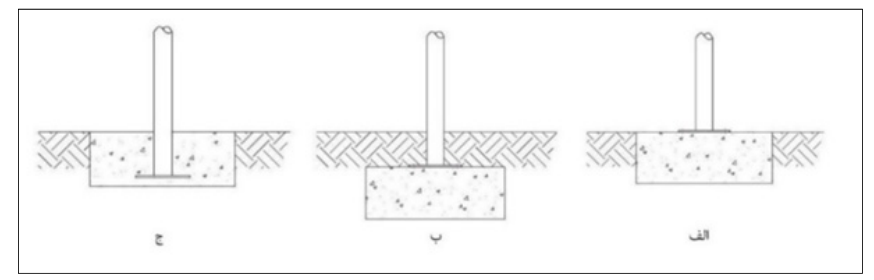

Figure 2. The installation on the surface, (b) the installation of concrete blocks, C: root installation. (Source: www.marshalls.co.uk/commercial)

According to the historical-cultural installation experiences in Tabriz, you can report install a variety of ways of installation and used for bench (Table 1)

Table 1. Availableandcustomaryinstallation way for the bench in the study area. (Source: authors) 


\begin{tabular}{|l|l|l|l|l|c|}
\hline & & & Schematic picture \\
of kind of \\
installation
\end{tabular}

\subsubsection{Type of Floor}

eight types of floor or coverings can be identified that urban furniture is usually installed and implemented on them. Features related to a variety of floor coverings, are summarized in Table 2. Most urban furniture, need smooth gradients to install. It should be noted that in all types of media if you need to e root planting practices, created hole in the ground filled with concrete. The screw bolts fixed to the concrete floor.

Table 2. Floor installation and its features. (Source: authors)

\begin{tabular}{|c|c|c|c|}
\hline Kind of bed & Application & $\begin{array}{l}\text { Kind of } \\
\text { installation }\end{array}$ & Appearance feature of installation \\
\hline concrete & $\begin{array}{l}\text { Concrete block which is } \\
\text { covered }\end{array}$ & mills & $\begin{array}{l}\text { Flat or pore surface. Strong } \\
\text { installation and modern appearance }\end{array}$ \\
\hline Paving & In streets and parks & $\begin{array}{l}\text { Root installation } \\
\text { and mills }\end{array}$ & $\begin{array}{l}\text { It is difficult to fix paving in } \\
\text { foundation and don't have } \\
\text { harmony }\end{array}$ \\
\hline Asphalt & $\begin{array}{l}\text { Observed in surface of } \\
\text { streets, concrete block }\end{array}$ & $\begin{array}{l}\text { Root installation } \\
\text { and mills }\end{array}$ & $\begin{array}{l}\text { The foundation can be pitch and } \\
\text { damage when filling }\end{array}$ \\
\hline Soil & $\begin{array}{l}\text { There are in streets and } \\
\text { gardens }\end{array}$ & $\begin{array}{l}\text { Direct or root } \\
\text { installation }\end{array}$ & $\begin{array}{l}\text { The advantage is that foundation } \\
\text { and mills can be hidden. But is } \\
\text { dirty }\end{array}$ \\
\hline Grass & $\begin{array}{l}\text { Observe in gardens and } \\
\text { parks in street }\end{array}$ & $\begin{array}{l}\text { Direct or root } \\
\text { installation }\end{array}$ & $\begin{array}{l}\text { Grass can hide installation system. } \\
\text { But can damage to installation } \\
\text { system. }\end{array}$ \\
\hline Stones & $\begin{array}{l}\text { Stone bed is less seen in } \\
\text { streets }\end{array}$ & Pneumatic mills & $\begin{array}{l}\text { Good and pleasant appearance but } \\
\text { furniture installation is difficult }\end{array}$ \\
\hline brick wall & $\begin{array}{l}\text { Installation to wall is less } \\
\text { seen, otherwise installation } \\
\text { on surface make difficulty }\end{array}$ & Pneumatic mills & $\begin{array}{l}\text { Installation system bring direct } \\
\text { user view and modern appearance }\end{array}$ \\
\hline $\begin{array}{l}\text { Install to other } \\
\text { urban } \\
\text { components }\end{array}$ & $\begin{array}{l}\text { Install to other urban } \\
\text { components is seen less, } \\
\text { otherwise low cost, low } \\
\text { space }\end{array}$ & Specific mills & $\begin{array}{l}\text { Minimizing foundation and } \\
\text { installation tools }\end{array}$ \\
\hline
\end{tabular}

\subsubsection{The Installation Process}

Steps and operations that are carried out in the context of an urban furniture intended to be installed is different according to the type of installation. You can step through the installation of urban furniture to suit the type of installation, summarized in Table 3.

Table 3. The installation process for the review with respect to the conventional type of installation. (Source: 


\begin{tabular}{|c|c|c|c|c|}
\hline & $\begin{array}{l}\text { Root installation } \\
\text { (direct installation in } \\
\text { the ground) }\end{array}$ & $\begin{array}{l}\text { Installation with } \\
\text { concrete block }\end{array}$ & $\begin{array}{l}\text { Surface installation } \\
\text { using masonry anchor }\end{array}$ & $\begin{array}{l}\text { Surface installation using } \\
\text { special masonry anchor }\end{array}$ \\
\hline $\begin{array}{l}\text { First } \\
\text { stage }\end{array}$ & $\begin{array}{l}\text { Specify place of } \\
\text { foundation }\end{array}$ & $\begin{array}{l}\text { Specify place of } \\
\text { foundation }\end{array}$ & $\begin{array}{l}\text { Specify place of holes } \\
\text { using similar tools }\end{array}$ & $\begin{array}{l}\text { Specify place of holes } \\
\text { using similar tools }\end{array}$ \\
\hline $\begin{array}{l}\text { Second } \\
\text { stage }\end{array}$ & $\begin{array}{l}\text { Make the hole on } \\
\text { foundation }\end{array}$ & $\begin{array}{l}\text { Make the hole on } \\
\text { foundation }\end{array}$ & $\begin{array}{l}\text { Specify place of holes } \\
\text { using similar tools }\end{array}$ & $\begin{array}{l}\text { Specify place of holes } \\
\text { using similar tools }\end{array}$ \\
\hline $\begin{array}{l}\text { Third } \\
\text { stage }\end{array}$ & $\begin{array}{l}\text { Pouring concrete on } \\
\text { hole }\end{array}$ & $\begin{array}{l}\text { Pouring concrete on } \\
\text { hole }\end{array}$ & $\begin{array}{l}\text { Cleaning hole by wire } \\
\text { brush }\end{array}$ & $\begin{array}{l}\text { Cleaning hole by wire } \\
\text { brush }\end{array}$ \\
\hline $\begin{array}{l}\text { Fourth } \\
\text { stage }\end{array}$ & $\begin{array}{l}\text { Placing foundation } \\
\text { on concrete }\end{array}$ & $\begin{array}{l}\text { Placing bullet on } \\
\text { holes in the furniture }\end{array}$ & $\begin{array}{l}\text { Placing special bullet } \\
\text { on the hole }\end{array}$ & $\begin{array}{l}\text { Injection of epoxy on the } \\
\text { hole }\end{array}$ \\
\hline $\begin{array}{l}\text { Fifth } \\
\text { stage }\end{array}$ & $\begin{array}{l}\text { Balancing mills on } \\
\text { the hole }\end{array}$ & $\begin{array}{l}\text { Placing bullet on the } \\
\text { foundation }\end{array}$ & Placing the furniture & $\begin{array}{l}\text { Placing bullet on the } \\
\text { concrete }\end{array}$ \\
\hline $\begin{array}{l}\text { Sixth } \\
\text { stage }\end{array}$ & $\begin{array}{l}\text { Until strengthen the } \\
\text { concert be patient }\end{array}$ & $\begin{array}{l}\text { Strengthen milling } \\
\text { on the hole }\end{array}$ & Placing washers & $\begin{array}{l}\text { Be patient to strengthen } \\
\text { epoxy inside }\end{array}$ \\
\hline $\begin{array}{l}\text { Seventh } \\
\text { stage }\end{array}$ & - & $\begin{array}{l}\text { Until strengthen the } \\
\text { concert be patient }\end{array}$ & Upper rolling & Placing the furniture \\
\hline $\begin{array}{l}\text { Eight } \\
\text { stage }\end{array}$ & - & Bullet rolling & - & $\begin{array}{l}\text { Placing washers in the } \\
\text { place }\end{array}$ \\
\hline $\begin{array}{l}\text { Ninth } \\
\text { stage }\end{array}$ & - & - & - & upper Rolling \\
\hline
\end{tabular}

\subsection{Beauty Street Furniture Installation}

From the eighteenth century onwards, aesthetics as a science, the natural sciences that way before, and like physics, chemistry or biology act with the methods of the action. However, it was found that aesthetics unlike the natural sciences, has emotional impact and it cannot be tested in the lab contract. On one hand, aesthetics such as psychology, the human inner, the perception and sentiment, sadness and joy, beauty and desire and instinct deals and on the other hand, the concept and its provisions relative intensity( Youssefian,2001) in the "Dictionary Dehkhoda "aesthetics, beauty and discipline of psychology that aims to make known the beauty and art) dictionaries Dehkhoda, p. 599)

Beauty has four basic types: (1) the subtle beauty (2) the natural beauty perceptible (3). Cosmetic or aesthetic value (4) absolute beauty (parsley, 162:2008). The beauty of the first significant expansion is to create a sensory delight times in all people. The second type of subtle natural beauty of freedom and omniscience. Beauty third means such as justice, morality, wisdom, courage and spiritual deliverance, which is due to knowledge and freedom. Given the visibility of street furniture in the public spaces of cities, with the aim of expanding the joy of the people, the beauty of the first tangible beauty, is a priority in this article.

There are three widespread and major approaches to understanding the beauty and tasteful ideas. A study of the concepts of aesthetics, or more precisely to the "critical languages" in which specific measures identified, and they provided the rationale and justification. (B) The philosophical study of some of the states of mind, reactions, attitudes and emotions that are involved in the aesthetic experience. A study in philosophical aesthetic objects. (Hasprz, 79:1991). In this study due to the nature of the object that a generic product is installed in the city, to assess the concepts of beauty and beauty of the method is used to get the concepts of Kansei engineering.

\subsubsection{Beauty Determining Factor in the Installation of Street Furniture}

If beauty is divided into two parts, decorative beauty and cosmetic applications, it can be said that beauty in industrial products, not just have a mere decorative but practical case will be the subject of the importance of aesthetics in commercial products. Beauty decorative aspects, defined in conjunction with user emotional needs and as a result, its respond is to the spiritual needs of the audience and to increase the quality of life (Hakimi Tehrani, 2011: 127).

One of the most important emotional users' needs is needs of beauty. According to the so-called beauty and conceptually vague, subjective, to meet these requirements must be considered as the user for a specific product or part of the harvest and the history of admiring the beauty is subjective. In other words, what concepts should be formed in users mind to see product in beautiful imagine. To get to the concepts and definitions Kansei 
engineering was used.

We want to know users (where here are citizens and tourists) the subject of the visual effects and often graphic and visual style benches installed with it, whether knowing the way beautiful or not what concepts and mentality classified. When it became clear concepts and mentalities, design and achieve a beautiful installation method from the perspective of citizens will not be too difficult. To achieve this component of beauty, Kansei engineering methods were used.

First, whatever the words are likely to be in the range of beautifully describes how to install street furniture collected, and any special assessment on them was carried out. These words from various sources such as books, magazines, media, internet and interviews with citizens were collected. Then synonymous words combine together and a word were selected as representative. This step was repeated several times until 11 words and installation method according to the target group (Table 1) were selected. These words are: Coordinator, impressive, clean, clear, simple, organized, good balance, attractive, powerful, reliable.

\section{Research Method}

The research, applied research, analysis and field studies, survey and data collection tools for observation and questionnaire is applied in the form of a study, an analysis of the study's data. The main research question is what causes the unpleasant and ugly fashions seen the installation of street furniture in our city and how will they control. To identify and assess ways of installing street furniture 56 questionnaires were distributed among the citizens and tourists in the area. The questionnaire distributed among different people at different times of the day and data were analyzed by SPSS software.

\section{Evaluation Methods of Installation}

There are two approaches and general method for the evaluation of urban beauty, expert-driven approach and people-centered approach. People-oriented assessment of reliability are high. The reliability of internal standards of aesthetic quality in small to medium groups of observers and judges (30 - 5) has been very high. The most common non-quantitative methods, questionnaire or survey is verbal (Karimi consultant, 50: 1392). Doing research on public opinion, need to be summarized and presented by experts in the form of spatial suggestions. In this research the results of the questionnaire are analyzed and the results are proposed to be offered.

Here's the beauty of technology assessment and selection of the method used: people are asked to show their favorite friendly or objects by choosing one over the other (paired comparison method) or by a standard rating on the object single. To determine which of the 11 selected word in Kansei method the most used among citizens and tourists admiring the beauty of urban furniture installation a pedestrian street test in the pass of Tarbiat, located in the historic district Tabriz, arranged.

\subsection{Introduction of Case Study}

City of Tabriz with one of the most important centers of ancient civilization and lasting social and political developments in the country during the last century and has always been regarded as the architect of much of what has taken place in Iran was considered. Among the ten regions of Tabriz, District 8 has a number of historical and cultural characteristics, including historical sites and cultural center of the city and actually tests it. This historical-cultural area, Pedestrian Street through a big training for a particular street passing pedestrians and cars which was not the right move. The street has historic buildings and malls and clothing stores and one of the main shopping centers of the city of Tabriz. Selection of participants is usually randomly based on indigenous and non-indigenous (tourists).

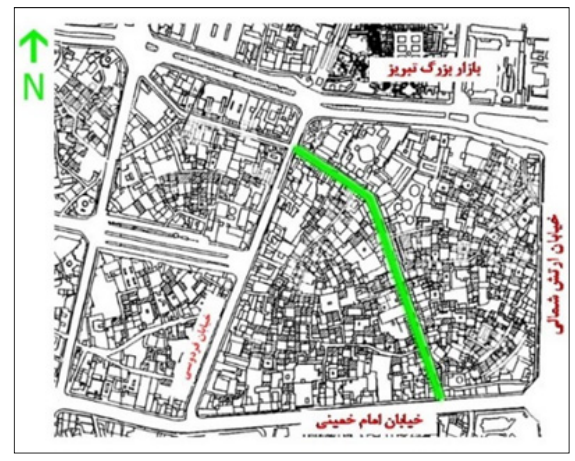

Figure 3. Plan implementation through great training, testing location. (Source: Time, 2009: 94) 


\subsection{Test}

should be installed only on the characteristics of the visual style done so through two-dimensional images only visual characteristics studied emotions to users in the same way that ordinary citizens in practice in most cases the conditions and how the installation of a visual connection with their urban furniture with it.

In this study all of ages and genders and social fabric used as the city of every kind and age and gender are present. The study included men and women of various ages 56 and 45 were tourists.

Four images of four different installation method and the differences beauty is in the eyes of the authors and producers with a list Kans final words (11 words) studied and tested to help with vocabulary, aesthetic characteristics installation method to be identified. Each image in a separate A4 sheets were horizontally with light gray background. In addition to eliminating the impact of color, all images were printed in black and white. We tried all four images at an angle of view and with the same dimensions of a product (bench), and in such a way that the installation method in a golden frame and focus the viewer. In the corresponding tab at the bottom of the picture, the 11 word was brought to the table that there is room for checking each word, to the perception of the image is in the form of specific words. (Table 4)

It should be noted that by survey the participants were also interviewed. They also face changes and reactions when reviewing projects carefully evaluated. Pictures bench frame so that the quality and how to install them easily recognizable to the interviewee, as well as the general form and other details of the bench is not a priority. The results of this survey are shown in Figure 1.

Table 4. Four different installation method for the study of Kansei words. (Source: author)

\begin{tabular}{|l|l|l|}
\hline Bench No. 4 & Bench No. 3 \\
\hline $\begin{array}{l}\text { Bench is totally steel with } \\
\text { root installation system }\end{array}$ & $\begin{array}{l}\text { Bench has steel } \\
\text { foundation with surface }\end{array}$ & $\begin{array}{l}\text { Bench has steel } \\
\text { foundation with surface } \\
\text { installation }\end{array}$ \\
\hline
\end{tabular}

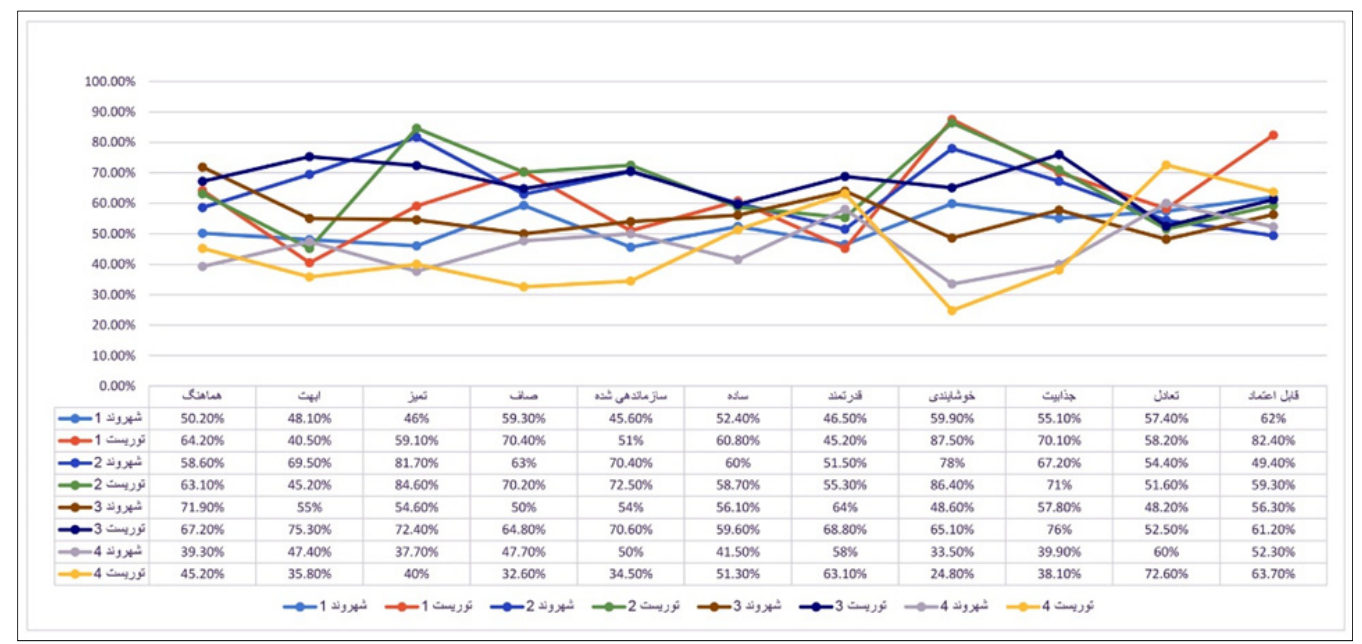

Figure 4. Chart frequency words extracted eleven percent Kansei engineering to help citizens and tourists with four benches from two perspectives. (Source: author) 


\section{Data Analysis}

Figure 1, range 11, obtained in this way are the words: pleasant, clean, attractive, impressive, organized, clear, reliable, harmony, balance, powerful, simple, which is replacement of the concept of beauty in particular cases.

Couch No. 1 in the opinion of citizens in terms of reliable, pleasant and smooth had highest frequency. And words organized, clean and powerful were the least frequent. And in the opinion of tourists a pleasant word, reliable and smooth with frequent and impressive words, powerful and organized were the least abundant.

Benches (2) in the opinion of the citizens in terms of clean, comfortable and organized had the highest frequency. And Words reliable, powerful and balance were the least abundant. And in the opinion of tourists Words pleasant, clean and organized, with the most frequent and imposing terms, the balance of power had the lowest frequency.

Benches (3) in the opinions of the citizens in terms of coordinated, powerful and charm were the most frequent. And Words balance, pleasant and smooth the least abundant. And in the opinion of tourists Words charm, grandeur and clean were with maximum frequency and balance words, simple and reliable was the least abundant.

Couch No. 4 in the opinions of citizens in terms of balance, powerful and reliable has the highest frequency. And words of welcome clean and had coordinated the lowest frequency. And in the opinion of tourists Words balance, reliable and powerful and the most frequent words pleasant, smooth and organized were the least abundant.

According to the results, it can be inferred that if the practices and systems of urban furniture installed in such a way that emotions such as happy, clean, attractive, impressive, organized, clear, reliable and harmony in viewers (citizen or tourist) was beautiful reinforce tobe installed. Since the installation method used for the majority of urban furniture and similar factors being installed in unseemly, almost as much as they are effective, to be used for the furniture poll conducted generalized.

\subsection{Causes Destruction and Ugly Latest Installation}

We want to know what factors cause that the concepts of beauty in installation, is less associated in the minds of citizens and tourists, in other words what are the factors that cause unpleasant, not clean, no charm, no grandeur, not to organize, and roughness In the mind of the viewer in the face of beauty street furniture installing. To extract these factors all possibilities in this regard were collected in 17 categories. A major cause of degradation and ugly latest installation of urban furniture that human beings has inconspicuous role, it can be pointed to these factors: the Earth Summit - floods - natural burnout materials - cracking due to freezing - or biomass - root

And human factors are: Improper placement, neglecting of floor installation - install Vandalism- weakness install, weakness in the implemented design changes in the layout of urban furniture -changing the application after install, changing the placement of furniture after installation, frequent use and poor in maintaining - lack of adequate in transportation, lack of coordination with other city agencies.

Then the factors affecting the beauty of the installation according to the degree of importance were ranked as more important be paid till the low-impact factors, removed or faded tobe seen. Prioritizing them based on the probability of their occurrence and impact with respect to this research (Objective The visual beauty installation method that is described with the concepts specified) has been carried out.

Each of the factors were compared and evaluated. Any agent with a particular letter, and after evaluation by Analytical Hierarchy Process (AHP), with the weighted index was assessed in relation to each other and the order of priority they are given in Table 8 . Any factor that placed in higher row has more possibility of causing the ugliness of installation city furniture. The value of each criterion is also specified.

Table 5. The order of priorities according to the importance of factors in the beauty installation. (Source: author)

\begin{tabular}{|l|l|l|l|l|l|}
\hline order & affecting factors & $\begin{array}{l}\text { Impact } \\
\text { factor }\end{array}$ & order & affecting factors & $\begin{array}{l}\text { Impact } \\
\text { factor }\end{array}$ \\
\hline 1 & $\begin{array}{l}\text { (J)weakness in the design of system } \\
\text { installation }\end{array}$ & 17.153 & 10 & (B)floods & 8.153 \\
\hline 2 & $\begin{array}{l}\text { (K)weaknesses in the } \\
\text { implementation phase of installation }\end{array}$ & 16.153 & 11 & $\begin{array}{l}\text { (M)Changes in the layout of } \\
\text { furniture after installation }\end{array}$ & 7.153 \\
\hline 3 & (G)lay out inappropriate & 15.153 & 12 & (F)root & 6.153 \\
\hline 4 & $\begin{array}{l}\text { (H) inconsideration of floor } \\
\text { installation }\end{array}$ & 14.153 & 13 & (P)lack of adequate transport & 5.153 \\
\hline
\end{tabular}




\begin{tabular}{|l|l|l|l|l|l|}
\hline 5 & (I)Vandalism & 13.153 & 14 & (L)for land use change & 4.153 \\
\hline 6 & (C)normal wear and tear Material & 12.153 & 15 & (A)Earth Summit & 3.153 \\
\hline 7 & O)lack of maintenance & 11.153 & 16 & (D)cracking due to freezing & 2.153 \\
\hline 8 & $\begin{array}{l}\text { (Q)lack of coordination with other } \\
\text { municipal organizations }\end{array}$ & 10.153 & 17 & (E) biomass & 1.153 \\
\hline 9 & (N)frequent use & 9.153 & & & \\
\hline
\end{tabular}

\subsection{Evaluation Procedures Included in the Installation (Based on Beauty Factors)}

Destruction and ugly possibility of installing the system in the desired area (Area 8 Tabriz) According to the probable cause ugly latest installation site will be evaluated to determine the best and worst of installation of systems with purpose in this study is specified.

The installation system according to any one of the factors influencing the aesthetics of 100 , a score will be given to those values is called (the score of 100, the mean scores the experts have given to that installed system). Then this score multiplied by the value (which was shown in Table 5) to obtained the actual value for the system installation.

Due to these factors, negatively expressed and whatever they score less than 100 points is sign of a better way to install as beautiful view, the functional value of each factor is reversed as a result of, for example, the value of $\mathbf{J}$ 1. $153,17.153$ factor is to be converted.

Table 6. Evaluation of existing installation practices with respect to factors in the beauty of the installation. (Source: author)

\begin{tabular}{|l|l|l|l|l|l|l|l|l|l|}
\hline & & \multicolumn{2}{l|}{ Installation by miller } & \multicolumn{2}{l|}{ Root installation } & \multicolumn{2}{l|}{ Wall installation } & \multicolumn{2}{l|}{$\begin{array}{l}\text { Direct } \\
\text { installation }\end{array}$} \\
\hline $\begin{array}{l}\text { Effective } \\
\text { factors }\end{array}$ & wf & Gv100 & Rvwf*gv & $\begin{array}{l}\text { Gv } \\
100\end{array}$ & Rvwf*gv & $\begin{array}{l}\text { Gv } \\
100\end{array}$ & Rvwfgv & $\begin{array}{l}\text { Gv } \\
100\end{array}$ & Rvwf*gv \\
\hline A & 15.153 & 40 & 3.92 & 85 & 8.3 & 5 & 0.49 & 5 & 1.49 \\
\hline B & 10.153 & 10 & 0.65 & 70 & 4.57 & 5 & 0.32 & 5 & 0.32 \\
\hline C & 6.153 & 35 & 1.37 & 45 & 1.76 & 20 & 0.78 & 5 & 0.19 \\
\hline D & 16.153 & 15 & 1.56 & 50 & 5.22 & 5 & 0.52 & 5 & 0.52 \\
\hline E & 17.153 & 10 & 1.11 & 40 & 4.44 & 45 & 5 & 10 & 1.11 \\
\hline F & 12.153 & 50.3 .92 & 65 & 5.09 & 5 & 0.39 & 5 & 0.39 & 0.39 \\
\hline G & 3.153 & 65 & 1.27 & 50 & 0.98 & 55 & 1.07 & 5 & 0.09 \\
\hline H & 4.153 & 70 & 1.70 & 75 & 1.96 & 40 & 1.04 & 20 & 0.52 \\
\hline I & 5.153 & 80 & 2.61 & 60 & 1.96 & 85 & 2.77 & 90 & 2.94 \\
\hline J & 1.153 & 75 & 0.49 & 70 & 0.45 & 85 & 0.55 & 10. & 0.06 \\
\hline K & 2.153 & 20 & 0.26 & 40 & 0.52 & 50 & 0.65 & 10 & 0.13 \\
\hline L & 14.153 & 10 & 0.91 & 25 & 2.28 & 40 & 3.36 & 45 & 4.11 \\
\hline M & 11.53 & 10 & 0.71 & 40 & 2.87 & 10 & 0.71 & 5 & 0.35 \\
\hline N & 9.153 & 60 & 3.52 & 50 & 2.94 & 70 & 4.11 & 15 & 0.88 \\
\hline O & 7.153 & 40 & 1.83 & 30 & 1.37 & 50 & 2.28 & 10 & 0.45 \\
\hline P & 13.153 & 55 & 4.67 & 20 & 1.69 & 30 & 2.54 & 20 & 1.69 \\
\hline Q & 8.153 & 45 & 2.35 & 55 & 2.87 & 20 & 1.04 & 5 & 0.26 \\
\hline & & TOTAL & 32.85 & & 49.27 & & 27.92 & & 14.5 \\
\hline
\end{tabular}




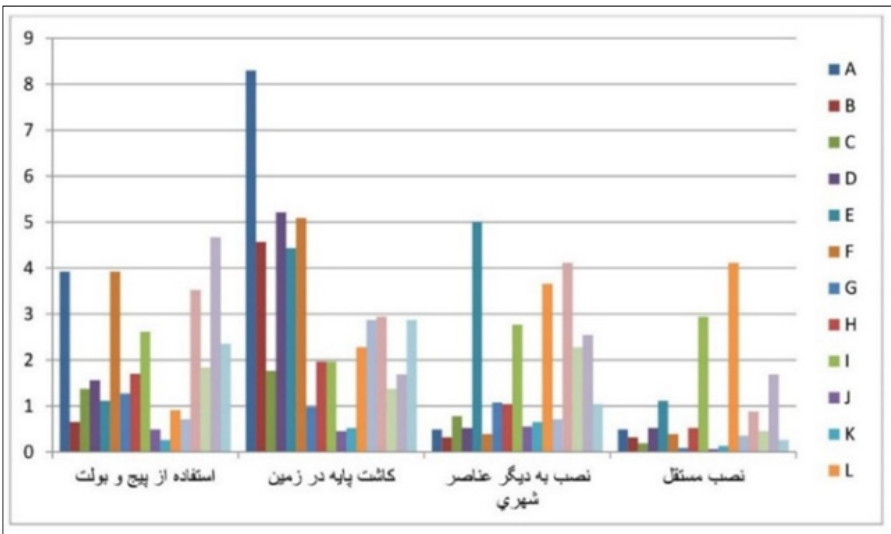

Figure 5. Chart: Evaluation of four existing installation practices with respect to factors in the beauty of the installation. (Source: author)

According to Table 6 and Figure 2 independent installation method to account for the fact that the lowest score is the best option to minimize the occurrence of unpleasant way for the installation of street furniture, especially the furniture (bench). Secondly, how to install other urban elements of interest.

\section{Conclusion}

The research focus on visual effects techniques of street furniture installation and as ample of urban furniture the bench, has been studied as the sample case in a specific are a called historical-cultural area of Tabriz that attention to the beauty in it increased. The results indicate that the current state of urban furniture installation practices in the study area is not satisfactory even though the measures of the purchase and installation of furniture and design at some point in particular is seen in Tarbiat president But also carelessness and negligence in the installation of this beautiful furnishings have been seen. Discussion beauty compared to other issues in urban furniture such as cost and the contractor is under contract at a very low level, while most communication of citizens with the urban elements will be done by looking.

According to a survey of citizens and they were asked to express beautiful urban furniture concept in a few words, and according to the images displayed on them these concepts were most frequent, clean, charm, grandeur, organized, clear, reliable, coordinated, balanced, powerful, simple, actually replacing the concept of beauty in this particular case. Since the installation method used for the majority of urban furniture was the same and the factors influencing the ugly being installed on their almost equally effective, questionnaire could be generalized for other furniture.

One of the factors that have the greatest impact on ugliness of urban furniture installation method in the study area is in order of priority as follows:

Poor system design, installation, weaknesses in the implementation phase of the installation, improper placement, lack of floor installation, Vandalism, natural burn out materials, poor maintenance, lack of coordination with other city agencies, frequently, floods, changing the furniture lay out after installation, root, lack of adequate transport, land use change furniture, subsidence, cracking due to freezing, biomass

Among the conventional installation methods to fix the furniture to the floor, the most used in the study area is in order of priority as follows:

$\varpi$ Installation root (base direct planting in the ground) -40 percent

ळSurface mounting (screw bolts and rivets special) - 40\%

$\varpi$ Independent installation without particular operations by $20 \%$

While the results of the assessment methods of installation, based on the following factors should be pretty effective, that is, if the installation method used with higher priority ugly possibility of installation will be less. The use of methods of installation in the area studied is almost picture perfect.

1. Independent installation without special operations

2. Installation to wall or other urban elements

3. Surface mount (screw bolts and nails special rivets) 
4. Root Installation (base direct planting in the ground)

\section{Suggestions}

According to the results of this case study is to be seen as beautiful and stay beautiful location of a proposed urban furniture. These suggestions are based on research results and the logical relationship between the elements of destruction and ugliness installation, and personal experience of the authors extracted and also was involved in writing proposals.

\section{Offer to designers}

If possible anti-theft installation method used. In this way, the possibility of damage to the installation of street furniture and thieving by thieves and Vandals decreased.

If possible for individual single basis be considered (at least not reduce the number of legs). Few foundations have many advantages, including less material, easier installation, lower installation and demolition

If possible installation method is hidden from direct users view. (Induction the concept of word filter installation)

Best option for installation method, is independent installation. (This type of installation, concepts such as cleanliness, harmony and smoothness will be installed as well).

If possible not using bright colors that may even more clearly show contamination. (Induction concept of a clean installation)

If possible for installing a special place and separated from the substrate be considered. (Induction of impressive concept and organized the installation)

Installation method designed to avoid accumulation of dirt and mud. (Induction concept of a clean and pleasant place of installation)

Installation method designed the way that running it for the person with the least expertise be possible, and what the designer had in mind implement perfectly.

If possible direct planting techniques used less on land. The implementation of this method of installation for uniform and good appearance is difficult.

Designers effort in making senses like a pleasant, clean, attractive, impressive, $\varpi$ organized, clear, reliable, harmony, balance, simplicity in installation method diligent and powerfulness

If possible, designers and urban furniture design special product offer suggestions for its layout.

\section{Suggest to manufacturers}

If possible, manufacturers, apply hardware installation with the original product not just to the installer choose the components Personalizing. (Provided by the manufacturer of parts and accessories for the installation of street furniture)

Manufacturers with the delivery of urban furniture, paper furniture provide technical direction on how to install it.

Use of modern tools such as rivets masonry fixing, use of epoxy resin and so on and provide images that how to properly use this tool for fixing the installer displays.

\section{Suggest to city officials}

Relevant organizations (municipalities) and its officials take care to installation issues how is predicted and are completely transparent to the manufacturer or ask your contractor.

Due to the exhaustion is one of the highlighted factors in unpleasant ways in installation, they period maintenance and protection must be taken seriously.

A process define monitor and document the installation and professionals train and apply for it.

For each urban furniture and installation a certificate prepared for the future, to create the ability to track and record.

\section{References}

Behzadfar, M. S. (2013). Analysis of the genealogy of urban aesthetics in dealing with the administrative structure of the city. Journal of Urban Management, 30, 90-69.

Chiellini, M. N., \& Khora, M. (2008). The impact and role of emotions in the process of product design Introduction to the methodology of Kansei engineering. International Journal of Engineering Sciences, 19(10-B), 151-160. 
Dstmalchyan, A. (2012). Overview on Citizens 'Rights, Ministry of Interior, Bureau of protecting the rights of citizens, the protection of citizens' rights directive agency programs.

Hasprz, J., \& Rajraskratn, T. (2001). Philosophy of art and aesthetics. Translation Jacob Azhand, Tehran: Tehran University.

Jafari , M. T. (2008). Beauty and the art of Islam. Tehran: The compilation and publication of parsley Sarlamh.

KarimiMoshaver, M. (2014). Approaches and methods in urban aesthetics. Journal of Garden View, 24, 56-47.

Khodadadeh, Y. N. T. (2009). Kansei Engineering: A Case Study of motion by helping the elderly. College of Fine Arts, 36, 59-63. Winter, Tehran University.

Madanipur, A. (2001). Urban Design view on the local community. Translation FarhadMortezaie, Tehran: Processing and urban planning.

Mortezaie, R. (2003). Approach in the design of urban furniture. Tehran municipal agency in the country.

Pakzad, J. (2007). Theory and urban design process. Tehran: Shahidi.

Pourtahmasi, S., \& Azar, T. (2012). Ights and citizenship education in Nahjalbalaqe. A research Alavi, the second year of the second number, Institute for Humanities and Cultural Studies, pp. 23-1.

Rahimi, T. A. (2011). Overview of Industrial Design, Tehran: Cultural Mirdaqshty.

Saeed, N. A. (1999). Municipal Green Book. Tehran municipal agency in the country.

Tavasoli, M. (1997). Urban Development and Architecture Research Center, Tehran. Urban Design, 2.

Youssefian, J. (2001). Take the concept of aesthetics. Journal of Literature and Human Sciences of AllamehTabatabai University, 135-178.

Zamani, B., \& Muhammad, T. P. (2009). historical-cultural education organization based in Tabriz. Client: Cultural Heritage, Handicrafts and Tourism, the executive body for the research center, restoration of historic monuments and sites Tabriz Islamic Art University, (Unpublished)

Zangiabadi, A. T. (1983). Design and planning of urban furniture. Mashhad: Sharia Birch.

Zangiabadi, A. T.(2008). Spatial analysis of tourism in the downtown section of urban furniture. Journal University of Isfahan, 22, 45-66.

\section{Copyrights}

Copyright for this article is retained by the author(s), with first publication rights granted to the journal.

This is an open-access article distributed under the terms and conditions of the Creative Commons Attribution license (http://creativecommons.org/licenses/by/3.0/). 